\title{
The Politics of Youth: Civil Rights Reform in the Waterloo Public Schools
}

\author{
KATHRYN A. SCHUMAKER
}

ON FRIDAY NIGHT, September 13, 1968, the East High School Trojans of Waterloo, Iowa, opened their football season against the St. Joseph Chargers of Westchester, Illinois. The game was played at Sloane Wallace Stadium at West High School in Waterloo, an all-white school on the predominately white side of town. East High, which all of the city's black high school students attended, had no stadium to house its top-ranked team. ${ }^{1}$

During the halftime lull, police officers attempted to arrest a young African American man outside the stadium. When the young man resisted arrest, students in the stands took notice and poured outside the gates. Black students scuffled with police for the remainder of the game. Groups of students argued with police, who tried to control them with mace and clubs. ${ }^{2}$

After the game's end, more chaos erupted across the Cedar River on the east side of town, where almost all of the city's Af-

Members of the University of Chicago Social History Workshop and participants in the University of Michigan Graduate Student Conference on the Long Twentieth Century read and provided many insightful comments on early versions of this article. I am especially grateful to Mark Bradley, Matt Briones, Jane Dailey, Chris Dingwall, Adam Green, Matt Lassiter, Amy Lippert, Sarah Miller-Davenport, Emily Remus, Emily Romeo, Jim Sparrow, Katie Turk, and Sarah Weicksel.

1. Waterloo Courier, 11/15/1967.

2. Des Moines Register, 9/14/1968.

THE ANNALS OF IOWA 72 (Fall 2013). (C) The State Historical Society of Iowa, 2013. 
rican Americans lived. Someone started a fire at a lumber company that quickly engulfed its mill and three nearby homes. At East High, another person poured gasoline and then threw a match through a classroom window. For hours, police officers skirmished with groups of young men. When the violence finally ended around midnight, seven police officers were wounded and thirteen young people had been arrested. The next day, the streets were deserted except for hundreds of National Guardsmen who patrolled the city's east side on foot with bayonets and in Jeeps and trucks stocked with smoke bombs. ${ }^{3}$

Civil disorder was not new to Waterloo; the summer before, another confrontation between a police officer and African American youths had sparked disorder that lasted several days. At the time, the editor of the Waterloo Courier commented to the New York Times, "We get calls from other newspapers and they all ask, 'What are they doing rioting out there in the cornfields?' "4 Young people in Waterloo were not, in fact, rioting in any cornfields, but the editor's statement indicates how "urban" problems were considered to afflict only big cities in far-off states. Yet in the late 1960s, even in places that looked very much like Waterloo, young people expressed their grievances and frustrations through instances of civil disorder.

CIVIL DISORDER and the threat of disorder were common during the late 1960s. The Kerner Commission noted that in 1967 there were nearly 70 instances of civil disorder in cities with populations of less than 100,000.5 Although the scale and length of the Waterloo disorder of 1968 did not come close to rivaling those in Newark or Detroit during the summer of 1967, which lasted for days and ended with dozens of deaths, the same frustrations instigated disorder in those large cities. Waterloo's smaller scale allows for a close analysis of how the dis-

3. Waterloo Courier, 9/15/1968; New York Times, 9/15/1968.

4. Waterloo Courier, 7/13/1967; New York Times, 7/14/1967.

5. According to the Kerner Commission, out of a total of 160 total instances of disorder in 1967, 37 occurred in cities with fewer than 50,000 inhabitants and 30 occurred in cities that had between 50,000 and 100,000 inhabitants. National Advisory Commission on Civil Disorders, Report of the National Advisory Commission on Civil Disorders (New York, 1968). 
ruptions of 1968 reverberated well into the next decade and illuminates the influence of youth politics on the city during those years.

Before 1968 Iowans had attempted to address the problems of racial discrimination and segregation in their state with a series of voluntary efforts. The civil disorder of 1968 spurred a coalition of residents, white and black, to coalesce around the need for further reform. What those reforms would entail remained a point of constant contention among students, parents, school administrators, and other residents. Through the debates of the following years, dismantling racial discrimination in the schools was at the forefront of community concerns - and it was pushed there by student activism.

After the national civil rights victories of the 1964 Civil Rights Act and the 1965 Voting Rights Act, implementation of the reforms those laws demanded remained an important and pressing problem. Scholars have neglected to analyze that process, focusing instead on a declension narrative of the post-1965 United States in which the nation became attuned to the efforts of civil rights activists in the North only when civil disorder and the rise of Black Power jolted its cities. That literature marries the urban crisis with the history of civil rights, and identifies suburbanization as key in unmaking the New Deal coalition of the 1960s. According to that narrative, segregation in northern schools was most often a product of residential segregation, which was amplified by white flight to the suburbs. Robert Self's American Babylon most forcefully frames the post-civil rights era within a metropolitan schematic with the indelible image of the "white noose" created by a mass white exodus from cities to suburbs. ${ }^{6}$ The black freedom struggle in the North, with its focus on access to jobs, the amelioration of poverty, and fair housing, was doomed by broader phenomena shaping the American landscape during the 1960s and 1970s, especially deindustrialization and white flight to the suburbs. Those factors contributed to the political influence of a resurgent conservatism, which further foreclosed possibilities for civil rights reforms during the

6. Robert O. Self, American Babylon: Race and the Struggle for Postwar Oakland (Princeton, NJ, 2003). 
1970s. ${ }^{7}$ White opposition to busing, perhaps demonstrated most notably in Boston, turned desegregation into a hot-button political issue at the expense of the children involved. ${ }^{8}$

Although suburbanization and the urban crisis profoundly shaped American politics in the second half of the twentieth century, that paradigm places a backlash to the racial liberalism of the 1960s at its center and ignores the complicated process that Americans faced in dealing with the changes in daily life wrought by the civil rights movement. Such a reliance on the macro-history of the era leaves out subtler transformations occurring in Americans' everyday lives. I argue that the late 1960s and early 1970s were also shaped by the new expectations created by the civil rights movement's successes - particularly the vision of equal schooling held by young people, who conceived of antidiscriminatory measures that would dramatically change the way children were educated and treated in schools. Those young people were emboldened by the new moral legitimacy given to civil rights reforms, and they demanded to be heard.

This telling of the story of the late 1960s shows how civil disorder was not just a symptom of a full-blown urban crisis but was also part of a larger struggle in the schools for what black students saw as their rights to equity in education and freedom from discrimination. Importantly, students in Waterloo were far less interested in desegregation than they were in implementing what they saw as a new standard of race relations between school administrators, teachers, and students. Inspired and empowered by the civil rights movement's successes in the

7. On the links between the rise of the New Right and suburbanization, see Kevin Kruse, White Flight: Atlanta and the Making of Modern Conservatism (Princeton, NJ, 2005); and Matthew Lassiter, The Silent Majority: Suburban Politics in the Sunbelt South (Princeton, NJ, 2006). Lassiter argues that a new "colorblind" political coalition of whites opposed busing to achieve school desegregation on the grounds that it infringed on their rights as homeowners in the suburbs. See also Joseph Crespino, In Search of Another Country: Mississippi and the Conservative Counterrevolution (Princeton, NJ, 2007); Rick Perelstein, Nixonland: The Rise of a President and the Fracturing of America (New York, 2008); and Laura Kalman, Right Star Rising: A New Politics, 1974-1980 (New York, 2010).

8. Ronald Formisano, Boston Against Busing: Race, Class and Ethnicity in the 1960s and 1970s (Chapel Hill, NC, 1991). See also Gregory S. Jacobs, Getting Around Brown: Desegregation, Development, and the Columbus Public Schools (Columbus, $\mathrm{OH}, 1998)$. 
mid-1960s, Waterloo students asserted their own conceptions of racial equality and educational equity and, in the process, won concessions from the local school district. At the same time, the school board turned to school desegregation as a practical way to prove its commitment to racial equality in the schools. Shrinking enrollments turned school desegregation into a policy choice made when it became apparent that a realignment of school attendance zones would be necessary. White opposition to busing arose in Waterloo as the school board voted for a comprehensive desegregation plan, but opponents were ultimately not able to halt the implementation of the school board's plan.

IN 1968 Waterloo was a deeply segregated city with roughly 75,000 inhabitants and a growing African American population. Waterloo's economic base was in farm equipment manufacturing and agricultural products processing. The major employers in the city during the 1960s were the Rath meatpacking plant and a large John Deere factory, which both employed unionized black and white workers. In 1970 a full third of the city's workers were engaged in manufacturing jobs-far more than in any other single sector of the local economy. During the early to midtwentieth century, the plants drew African American migrants from the South, who appreciated the factories' well-paying jobs and the promise of escape from the oppression of the Jim Crow South. By 1970, 9 percent of the city's inhabitants were black, and Waterloo was home to the third-largest African American population in the state behind Des Moines and Davenport. African Americans were concentrated in five of the city's neighborhoods, all of which were on the northeast side of the Cedar River. ${ }^{9}$

The civil rights struggle in Iowa dated back to the nineteenth century. In 1868, a century before the student protests at East High School, Iowans voted in favor of five amendments that erased references to race in its state constitution. The amendments extended the franchise to African American men and lifted a ban on their service in the state militia. They also struck

9. U.S. Commission on Civil Rights (USCCR), School Desegregation in Waterloo, Iowa (Washington, DC, 1977), 1-2. 


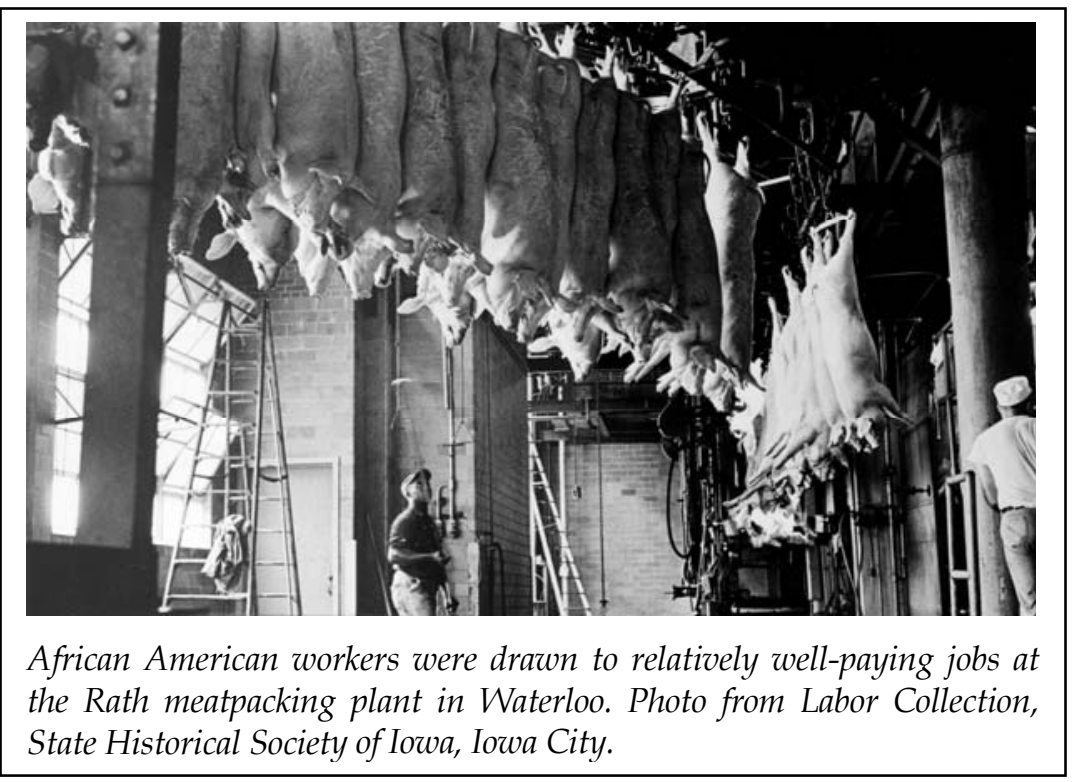

the word white from considerations of state census enumerations and legislative district apportionment. ${ }^{10}$ Historically, Iowa legislatures and courts were liberal in protecting the civil rights of the state's inhabitants - if only in word and not in deed. Civil rights statutes had been a part of Iowa state law since the late nineteenth century, but they proved difficult to enforce. Segregation developed despite the state's image as a pioneer of racial liberalism. ${ }^{11}$

10. Robert R. Dykstra, Bright Radical Star: Black Freedom and White Supremacy on the Hawkeye Frontier (Cambridge, MA, 1993), 224.

11. According to George William McDaniel, "Trying Iowa's Civil Rights Act in Davenport: The Case of Charles and Ann Toney," Annals of Iowa 60 (2001), 23538 , in Iowa "it was virtually impossible to get a white grand jury to return an indictment in a civil rights case." On the persistence of racial discrimination in Iowa in the twentieth century, see George William McDaniel, "Catholic Action in Davenport: St. Ambrose College and the League for Social Justice," Annals of Iowa 55 (1996), 239-72; Katrina M. Sanders, "The Burlington Self-Survey in Human Relations: Interracial Efforts for Constructive Community Change, 1949-1951," Annals of Iowa 60 (2001), 244-69; and Noah Lawrence, "'Since it is my right, I would like to have it': Edna Griffin and the Katz Drug Store Desegregation Movement," Annals of Iowa 67 (2008), 298-30. On the development of liberal civil rights laws in Iowa during the nineteenth century, see Dykstra, Bright Radical Star; and Leslie Schwalm, Emancipation's Diaspora: Race and Reconstruction in the Upper Midwest (Chapel Hill, NC, 2009), 198-200. 
After years of sometimes violent white resistance to the public education of African American children in white schools in the state, the Iowa Supreme Court ruled against segregation in public schools in 1868, stating that for the state to permit segregation "would be to sanction a plain violation of the spirit of our laws [and] tend to perpetuate the national differences of our people and stimulate a constant strife." The ruling, which declared that "all youths are equal before the law," was remarkable not just for its condemnation of school segregation nearly 90 years before the U.S. Supreme Court's decision in Brown $v$. Board of Education (1954), but it also marked a departure from supreme court decisions in other states that upheld segregated schools elsewhere in the nation. Despite the court's plain language striking down de jure segregation in Iowa schools, residential segregation ensured that the tradition of sending children to schools in their neighborhoods would create and maintain school segregation. 12

Efforts to end housing discrimination culminated in a minor victory in the late 1960s. In 1967 the state legislature passed a fair housing amendment to its civil rights bill, but an individual filing a claim had to submit a $\$ 500$ bond-an amount roughly equivalent to $\$ 3,500$ in 2013 . That provision created a significant obstacle for complainants - and not just because it required the deposit of a large sum of money; anyone found to have filed a false complaint would lose the bond. ${ }^{13}$ The fair housing law demonstrated the difficulties that plaintiffs in discrimination cases faced, and it indicates why cases were rarely pursued. In

12. Clark v. Board of Directors, 24 Iowa 266 (1868); Roberts v. Boston 59 Mass (5 Cush.) 198 (1850); Schwalm, Emancipation's Diaspora, 198-200. The state legislature also enacted a public accommodations law in 1884 after the U.S. Supreme Court struck down the federal law in the Civil Rights Cases. McDaniel, "Trying Iowa's Civil Rights Act in Davenport," 235-38.

13. Iowa's state legislature voted to repeal the $\$ 500$ bond provision in 1969. Congress passed a federal open housing law in April 1968, just one week after Martin Luther King Jr.'s assassination, although the law did not apply to singlefamily units until January 1,1970 - the type of housing most prevalent in small cities like Waterloo. Iowa Civil Rights Commission, Fourth Annual Report: 1970 (Des Moines, 1970), www.state.ia.us/government/crc/docs/annual70title .html; New York Times, 4/12/1968. For comparisons of dollar values, see U.S. Department of Labor, Bureau of Labor Statistics, Inflation Calculator, www.bls.gov/data/inflation_calculator.htm. 
1968 only nine individuals filed complaints about housing discrimination with the state's Civil Rights Commission. ${ }^{14}$ With the alleged victims of discrimination shouldering the burden of proof, prosecuting such cases could be expensive and ineffective. By the time the young people at East High rebelled in 1968, the state had a century-long history of racial discrimination and segregation existing alongside some of the nation's most liberal civil rights laws.

As was the case in cities across the nation, local residential segregation in Waterloo created racial segregation within the city's schools. In 1963 Waterloo's African American children attended 11 of its 40 public schools. Eighty-one percent of the city's white children attended schools that were at least 90 percent white, and many schools had no black students at all. ${ }^{15}$ Even though African Americans made up a relatively small percentage of the city's population, one elementary school had a student population that was 99 percent black, two had populations that were approximately 50 percent black, and another had a student population that was one-third black. In 1967, the year before the disturbances at East High erupted, African American students made up about one-fifth of that school's population of 1,700. There were no black students at West High on the other side of town, the site of the football game. ${ }^{16}$

YOUNG AFRICAN AMERICANS in Waterloo targeted the ways that racial discrimination in the public schools permeated the curricula and interpersonal relationships. In late August 1968, just weeks before the disturbances, Terri Pearson, an honors student at East High, and her younger sister Kathy handed a list of grievances to the school's principal, Lawrence Garlock. The students' decision to create and present a petition reflected a tradition established by other student protests of the 1960s, including Students for a Democratic Society's 1962 Port Huron

14. Iowa Civil Rights Commission, Third Annual Report: 1969 (Des Moines, 1969), www.state.ia.us/government/crc/docs/annual69compliance.html.

15. Minutes, Waterloo Commission on Human Rights, 9/7/1967, folder: Waterloo Commission on Human Rights, 1967, box 22, Merle Fleming Papers, Iowa Women's Archives, University of Iowa Libraries, Iowa City.

16. USCCR, "School Desegregation in Waterloo," 6. 
Statement and the demands supplied by students advocating the establishment of ethnic studies departments on college campuses. The Pearson sisters' list enumerated a number of complaints, including demands for a course in black history, integration of the entire social studies curriculum, and the hiring of more black teachers and counselors. Students also wanted permission to establish a black student union. These demands reflected a desire to change the everyday experiences of black students at East High and align them with what the students believed was a proper set of antidiscriminatory mores that should govern student and teacher behavior. ${ }^{17}$

The petition was the first indication that the autumn would be long and difficult at East High, with black students committed to the cause of civil rights reform. Garlock acknowledged the complaints but refused to agree to any immediate changes. When he assured the young women that a faculty committee would look over the list, Terri Pearson informed him that other black students did not want to continue to wait for action. A delayed response, she said, might come "too late." Concerned that Pearson's words portended trouble, Garlock wrote her a letter a week later, warning that any disruptions might result in suspension or expulsion of the involved students. He again assured her that a special committee would review the grievances "in a few weeks" and stated that any disruptive behavior "would be unfortunate as any grievances might be settled in a more reasonable fashion." 18

At noon on Monday, September 9, a handful of young black men entered East High School and demanded to meet with Garlock. At the same time, someone set off the fire alarm, evac-

17. Minutes, Board of Directors of the Waterloo Community School District (hereafter cited as School Board Minutes), 9/12/1968, Waterloo Community School District Administration Building, Waterloo. For more on petitioning and college student protests, see Carlos Muñoz Jr., Youth, Identity, Power: The Chicano Movement (London, 1989); and Martha Biondi, The Black Revolution on Campus (Berkeley, CA, 2012).

18. Iowa State Department of Public Instruction (DPI), "Report of Committee Named to Investigate the Background of Developments Culminating in the Closing of Waterloo's East High School," Feb. 1969, box 8, Waterloo Urban Ministry Records, Special Collections, Rod Library, University of Northern Iowa, Cedar Falls. 
uating students and teachers from the building. After it was declared a false alarm, the group of young men returned, accompanied by several black students from East High. They spoke to a teacher and, echoing the concerns presented by Terri Pearson a few weeks earlier, demanded that black history be integrated into East High's social studies curriculum. A teacher tried to assuage them by promising that a community meeting to discuss the proposed black history course would be held the next day after school. At the meeting, students, parents, teachers, and administrators could air concerns about the school's curriculum and discuss possible solutions. The crowd dispersed for the afternoon, but the seriousness of black students' concerns was clear. ${ }^{19}$

Publicly East High's administrators denounced the confrontation at East High while they quietly began to take action to subvert further disturbances. The following morning, Tuesday, September 10, the superintendent and principal met with a group that included black parents and current and former students to discuss potential curriculum changes. Despite the principal and superintendent's resistance to offering concessions to the students, the young men present were vocal about their desire to see East High treat black students more fairly. The school's director of instruction was present, as were East High parent and NAACP member Ada Tredwell, former East High student Charles Derden, and several current students. Although the curriculum committee did have a revamped plan for the school's social studies curriculum that integrated more African American history, Derden insisted that students would prefer an elective course focused solely on black history. ${ }^{20}$ The committee tentatively agreed to curriculum reform as a concession to the students.

The committee also decided to cancel the mass meeting scheduled for that afternoon, fearing that they would not be able to control the tone and tenor of the discussion. The students present at the meeting in the morning vehemently condemned the decision. "We're not fooling around anymore," warned one

19. Waterloo Courier, 9/10/1968.

20. DPI, "Report of Committee," 8. 


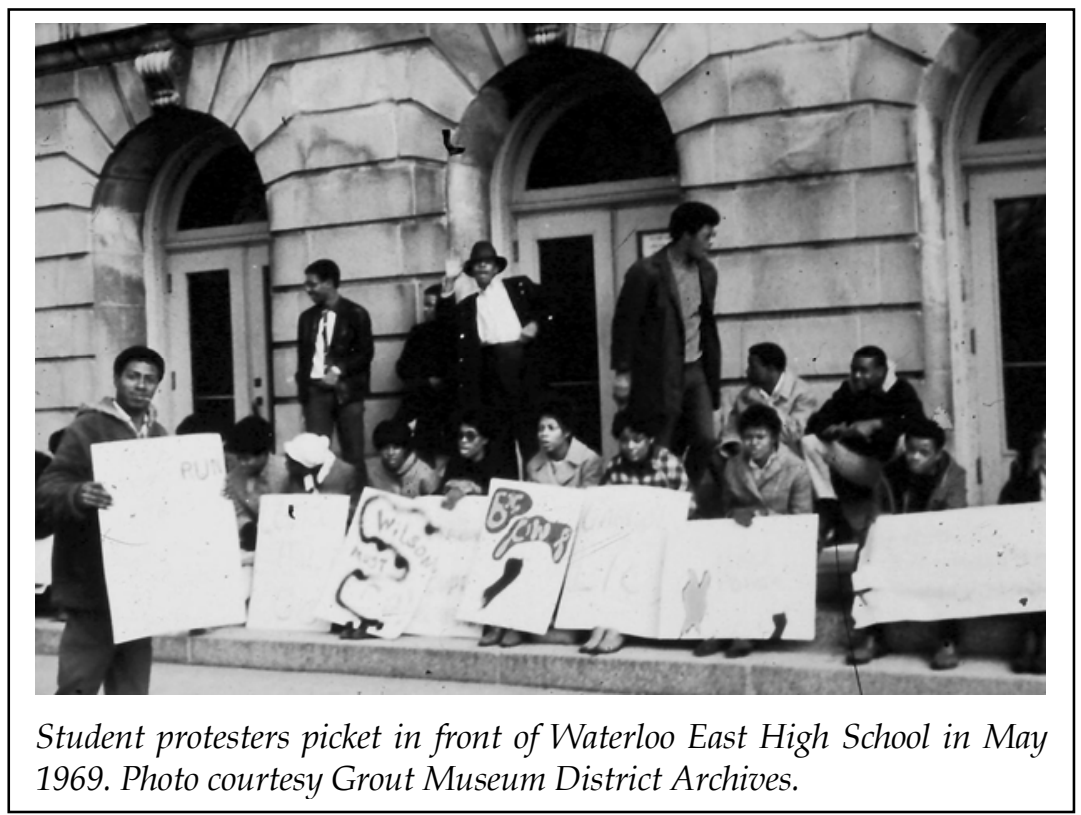

young man. "We're going to get what we want. ... We're going to be at East High and there better be a meeting." Another agreed, adding, "Don't have any police over there. I know those kids. If there are police, there will be trouble." The students were angered by the committee's decision; they demanded to be taken seriously and have their grievances heard. In warning the committee that canceling the meeting could lead to trouble, these young people brandished the most powerful weapon they had: adults' fears of youths' indifference to authority - and their willingness to cause trouble if they considered it necessary. ${ }^{21}$

The students' warnings proved convincing. Despite the administrators' attempts to avoid confrontation at the school, they could not simply dismiss a protest so large and determined. At 3:05 p.m., students were informed that school was dismissed and that all students except those on the football team should leave the building immediately. A crowd of nearly 100 young men and women gathered outside; some were students, and some were not. Garlock attempted to placate the protesters by reminding them that East High's curriculum techni-

21. Ibid.; School Board Minutes, 9/12/1968. 
cally did have a course on African American history - though the school had never hired anyone to teach it, ostensibly because they could not find anyone qualified to do so. ${ }^{22}$ The crowd eventually disbanded, but students did not waver from their promise to use disruption as a means to wrest power from the administration and school board.

The protests continued the next day. On Wednesday, 40 students walked out of class in support of the proposed curricular changes. After dismissing school early, the Waterloo school board met in an emergency session to discuss the course of action they would take to prevent the situation at East High from escalating. At the meeting, Jimmie Porter, the father of an East High School student, gave the school board another list of grievances created by students. The board promised to consider the grievances and agreed to appoint an African American to its curriculum committee. The board also canceled classes on Thursday and Friday but decided not to reschedule the fateful football game between East High and St. Joseph's. ${ }^{23}$

The East High administration, the school board, and the local newspaper all sought to delegitimize the actions of the protesters by arguing that they were criminals and not members of the community. Scoffing at the idea that the protests were a legitimate form of speech, Superintendent George Hohl attempted to discredit them by accusing "outsiders" of stirring up trouble. "This is a group of young adults not in a position to tell professionals who have worked on the problem for months whether it should be integrated or not, because, I submit, they know very little, if anything, about it," Hohl told the Waterloo Courier. Hohl blamed student protests at colleges across the nation, claiming that the student movement and the New Left-not legitimate grievances by the students themselves - were responsible for the unrest in Waterloo. He did warn that, although East High students had been innocent bystanders, "with outsiders coming in, violence could erupt." 24 The local newspaper reported that the police department had identified the protesters as "militants

22. Waterloo Courier, 9/11/1968.

23. School Board Minutes, 9/12/1968.

24. Waterloo Courier, 9/10/1968. 
and agitators," and the paper listed the names and criminal records of seven of the young male participants; all were between the ages of 17 and 21, and all resided in Waterloo, but none were currently students at East High. ${ }^{25}$

The young people who protested at East High that week were not outsiders. They included current and former students whose complaints were rooted in their personal experiences of discrimination at East High. Their grievances indicated frustration with student-teacher interactions. The students demanded, for example, that "teachers and counselors shall not discourage students of any race from attending the college of their choice" and not "interfere with the personal lives of the students." Students complained that teachers would break up groups of black students standing in the halls but allow white students to congregate freely. They also charged that teachers actively discouraged interracial dating, even calling parents of white students to inform them that their daughters were dating black students. ${ }^{2} 6$ The students demanded that teachers "who do not feel they can treat or teach black students as equals to white students" resign or be fired. ${ }^{27}$

In comments at the mass school board meeting on Friday afternoon, Charles Derden was particularly vehement that teachers not discourage black students from applying to the schools of their choice. Derden, a pre-law student at the University of Iowa, had been East High's valedictorian in 1965. He claimed that discriminatory actions by white teachers and counselors had persisted for years. During his senior year at East High, Derden recalled, he had received letters from universities across the nation. "I was told to go to the State College of Iowa because I 'could not compete' in those schools." "I went to the University of Iowa," Derden stated, "because I didn't believe everything that the white man told me about myself. But if I hadn't believed any of it I would be in a better school today." Derden's commitment to protest in Waterloo did emanate in part from his activism at the University of Iowa, where he was also involved in agitation to estab-

25. Waterloo Courier, 9/12/1968.

26. DPI, "Report of Committee," 20.

27. School Board Minutes, 9/13/1968. 
lish a black studies department. But his complaints also arose from his own experience in the Waterloo schools. He returned to Waterloo to provide his organizing experience and participate in the protests at East High in solidarity with current students. ${ }^{28}$

In an attempt to prevent the situation from escalating, the school board met again on Friday afternoon, just hours before the football game's kickoff-and the disorder that would ensue. The board agreed to capitulate to some, but not all, of the students' demands. At the crowded meeting, which attracted 300 community members, board president Sydney Thomas read aloud the 12 grievances and answered each one with a statement from the school board. The board acknowledged the lack of black teachers in the school system and assured the audience that the schools would continue to work toward hiring African American teachers. The board also reaffirmed its commitment to offering a separate course in black history, although it claimed that it was delayed because of the school's unsuccessful attempts to find and hire qualified African American teachers. It also assented to the students' request that they be called Afro-American or black-not Negro. The board refused to permit students to form a black student union, even though students promised that the organization would be open to both black and white students who wanted to join. Betty Jean Furgerson, an East High graduate and the leader of the Black Hawk County Head Start Program, stated, "The events leading up to this tragedy stem from the fact that the black students at East want a course in black history. They are asking for relevant education. The kids feel that they need it, and I'm proud they do. The whole thing grew up because nobody listened to what was being said." 29

Jimmie Porter, an East High parent, reiterated the students' frustrations with the school board's patronizing attitude. Porter demanded that the board take the students' grievances seriously. "You're not talking with kids," Porter stated at the Friday afternoon hearing. "You're talking with a man. . . . We came here with good intentions to work these problems out and come to a quick solution," Porter told the board. He added, "I don't trust

28. DPI, "Report of Committee," 19; Iowa City Press-Citizen, 11/21/1968.

29. Waterloo Courier, 9/15/1968; DPI, “Report of Committee," 17. 


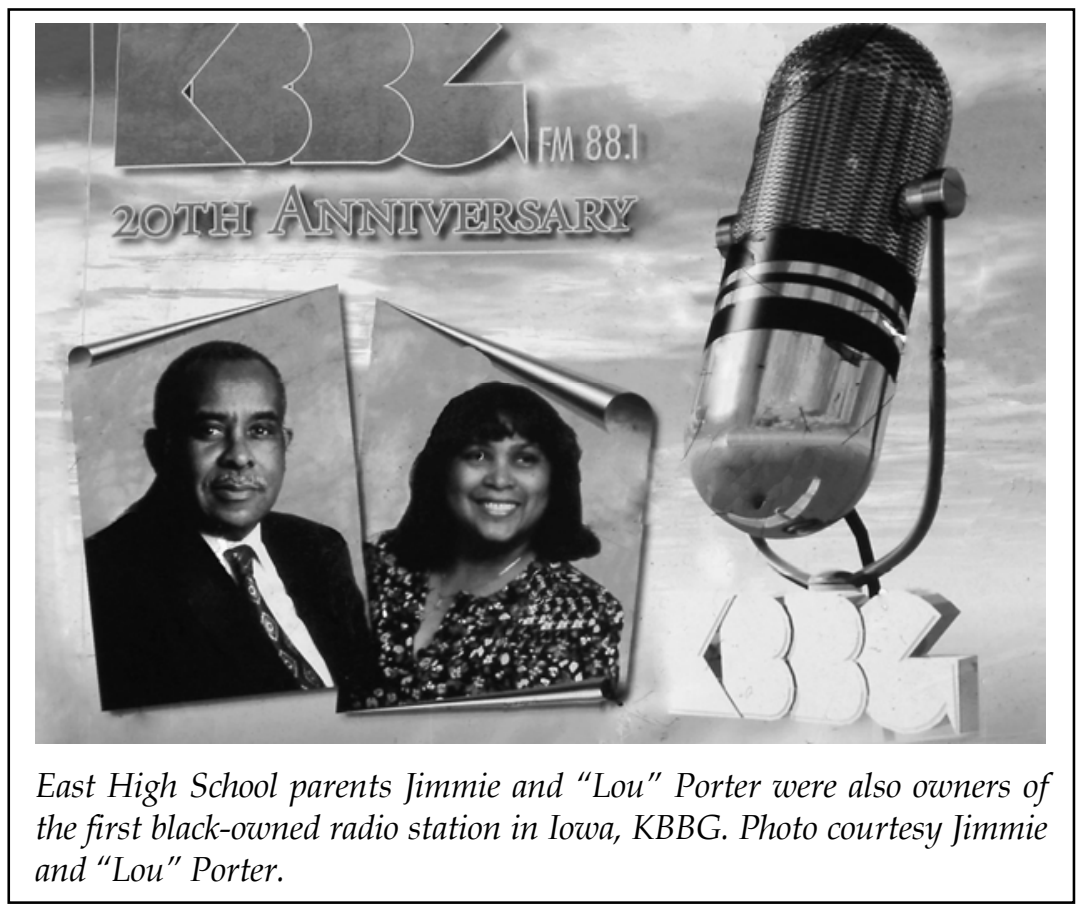

any of you and you don't trust me." Porter was a prominent figure in Waterloo's black community. He had arrived in Waterloo in 1948 from Mississippi, hoping to find a job in the John Deere factory and an escape from Jim Crow. He was, as he put it, "looking for the promised land." What he found disappointed him. Whites in Waterloo had, in his words, "domesticated" the black population. Segregation was not the law, as it was in the South, but whites in Waterloo had perfected informal methods of establishing white supremacy. Years later Porter observed, "I pretty well knew where I stood in Mississippi, and here I had to be told and reminded." 30

The school board held another mass meeting on Monday, the first following the civil disorder at the football game. Once again, young people came to the meeting to articulate their demands. Terri Pearson again requested permission to form a

30. Rick Halpern and Roger Horowitz, Meatpackers: An Oral History of Black Packinghouse Workers and Their Struggle for Racial and Economic Equality (New York, 1999), 128. 
black student union, which she said would "promote better understanding between black and white students at East High and better understanding between the students and the faculty." It would also serve to "encourage more participation from black students in the total activities of East High and to encourage black students to strive for higher scholastic achievement and prepare themselves to compete in our world today." The board refused the request, claiming that the club was racially discriminatory. When board members expressed exasperation with the frequency of meetings, Dwight Bachman, a senior at the nearby University of Northern Iowa, warned that things would only get worse if the administration did not act soon. "If you say this is not our matter we have plans for you that will not make you very comfortable," warned Bachman. When pressed to explain what he meant by those "plans," Bachman replied that he and others would show up at every school board meeting until they got what they wanted. ${ }^{31}$

THE CIVIL DISORDER that began at Friday's football game was fed by the growing frustrations that young African American men and women in Waterloo felt in the face of discrimination and segregation within the community. Confrontations between young men and police officers were endemic to black life in Waterloo; members of the black community perpetually complained of police brutality, and even the mayor admitted that police-community relations were toxic. The previous summer, the death of a young man, Eddie Wallace Sallis, in the city jail had aroused suspicion and concern that police brutality had been a factor. On May 31, 1966, Sallis and another young man, Howard Calvin Saunders, had been arrested in Waterloo on suspicion of being involved in a break-in. In the early morning hours of June 1, officers claimed that they had found Sallis hanged in his jail cell. "How could a man hang himself in jail if he is wearing only jeans?" asked Anna Mae Weems, an NAACP member and packinghouse worker at Rath. Sallis's death was ruled a suicide, although many suspected foul play. ${ }^{32}$

31. DPI, “Report of Committee," 35-36.

32. Waterloo Courier, 6/2/1966, 6/29/1966. 
The protests and civil disorder elicited a harsh reaction from the city's police department, which promised to "deal head-on with the problem that faces our community with strict enforcement and by taking strong action for which we have full support of our city administration." Other residents were more sympathetic to the students' complaints and acknowledged the existence of discrimination and inequality in the city. ${ }^{33}$

Although some were more supportive of the students than others, most residents recognized that the instances of civil disorder were symptoms of the persistence of racial discrimination and the culmination of years of discontent within the city's black neighborhoods. Teachers at East High released a statement that declared, "The East High School faculty feels that the present situation at East High is only a part of a national social condition. They also feel that the entire Waterloo community is responsible and must be involved." 34 The school board released its own statement on the disturbances at East High that chastised students who had contributed to the disruption while calling for community self-examination. Denouncing the "tragic lawlessness" of the instances of civil disorder, the statement nevertheless declared,

The events of Friday night seem to indicate that the underlying problem in Waterloo is more than a problem of educational policy, and is one which will require the efforts of the total community to resolve. ... From this point, it is the responsibility of all of the citizens of the City of Waterloo and of the Waterloo Community School District to restore an atmosphere of calm and reason. ${ }^{35}$

The faculty and school board's statements underscored the agreement that although they did not necessarily condone the method of students' protests, their complaints were not necessarily illegitimate. Others outside the schools agreed. Twenty-two Methodist ministers from Waterloo signed a statement that blamed the violence on "sicknesses long neglected" and proclaimed

33. School Board Minutes, 9/11/1968.

34. School Board Minutes, 9/16/1968.

35. "Public Statement by the Waterloo Community School District," School Board Minutes, 9/14/1968. 
that "massive healing must take place to prevent recurrences of the same." 36

In the following months, conversation in the city continued to use the civil disorder as a touchstone for a plan for community action, although the focus of those efforts shifted in crucial ways. Whereas the students' grievances emphasized the need to empower African American students and break down barriers to equal opportunity, the solutions sought by the school board turned to desegregation, placing segregation rather than inequity at the center of the debate. Although students had provided the impetus for reform, the board opted for school desegregation, even though it had never been a part of students' demands.

The students succeeded on a number of issues, particularly on the inclusion of black history in East High's curriculum and the hiring of two black teachers by mid-October. In late November, the school board unanimously approved a resolution to create a citizens advisory committee made up of a "representative" group -in other words, a coalition that included whites and African Americans - who would "study the problems .... in connection with providing all children in the school district with maximum educational opportunities, particularly the problems resulting from a concentration of black children and culturally deprived children in certain schools." 37 Problems within the Waterloo schools arose primarily from segregation and minority concentration, according to the board, an assertion that shifted concern to the makeup of the student body, not the quality of teacher-student relations or the schools' curricula.

THE DISTURBANCES at East High and in Waterloo's black neighborhoods set in motion a series of actions by local and state authorities that would profoundly shape school policyalthough not necessarily as the students had intended. In the week following the incidents, the county attorney announced that he would convene a grand jury to investigate the violence and arson. The grand jury's task was to issue indictments for any crimes committed during the disturbances. It did not, how-

36. Waterloo Courier, 9/20/1969.

37. School Board Minutes, 11/25/1968. 
ever, indict any person for any crime. In an unusual move, the grand jury unofficially indicted the community as a whole for its role in creating an atmosphere that led to civil disorder. According to the grand jury, "It is the present finding of the grand jury that our schools be geared toward the present society. . . I It is the obligation of the public school system to take a giant step in that direction by eliminating de facto segregation at once." The report concluded, "The grand jury recommends immediate integration at the elementary level." A year later, the grand jury released another report, documenting the changes that had been implemented in the community and recommending desegregation at all levels. ${ }^{38}$

Mayor Lloyd Turner denounced the grand jury's report. It placed all of the blame for the disturbances, he complained, on "the shoulders of whites." Turner accused the grand jury of not giving enough credit to the city's and state's civil rights reforms, and he pointed to the new fair housing law as evidence of progress in race relations. He failed to mention the housing law's prohibitive bond provision. ${ }^{39}$

Discussions of the potentially negative effect of segregated schooling on children were not new to the board or the city, but the civil disturbances made the issue seem more urgent. The year before, the school board had identified racial segregation as a problem in its schools but refused to accept any blame for its existence and refrained from proposing any mandatory solutions. The 1967 report of its newly formed Advisory Committee on Equal Education Opportunity emphasized the need to reduce the segregation of African American students in a few schools, although the committee restated the board's "conviction that it has not at any time allowed practices which would artificially establish or maintain segregation or discrimination, whether ethnic, religious, or racial." 40 It was no secret that African American

38. Waterloo Courier, 9/20/1968; DPI, Technical Assistance Report on School Desegregation and Integration: Waterloo, Iowa (Des Moines, 1970), 13, in box 8, Waterloo Urban Ministry Records; KWWL “Viewpoint," 2/7/1970, folder 2, box 1, James Sage Papers, State Historical Society of Iowa, Des Moines.

39. Waterloo Courier, 2/5/1969.

40. Advisory Committee on Equal Educational Opportunity in Waterloo Public Schools, "Final Report and Recommendations to the Waterloo Board of Education," School Board Minutes, 12/28/1967. 
children attended just a few of the city's schools, but the school board would not admit that it was the fault of the state or the school district.

Despite its previous unwillingness to admit fault in the segregation of Waterloo's schools, the school board did vote in the spring of 1969 to enact a policy of open enrollment for the following school year. That policy allowed a student to transfer to any school of his or her choice as long as the transfer promoted a "favorable" racial balance. ${ }^{41}$ Dissatisfied with the board's tepid policy, parents presented 200 letters in support of "the principle of total integration," demanding decisive action in May 1969.42 While the school board voted to commit itself to "the elimination of the heavy concentrations of minority group and disadvantaged" students in Waterloo schools and to "develop plans to achieve this end" in the fall, it remained committed to the idea that the schools would be desegregated voluntarily through open enrollment. The chair of the school board emphasized that he believed that only a voluntary plan would gain full community acceptance. Dr. Robert Harvey, the board's sole African American member, disagreed that full support was desirable. "If the policy is to work, some people will have to be bused who don't want to be bused," Harvey concluded. White parents would be reluctant to send their children to schools on the city's east side, so the burden of desegregation would remain on black children and parents. The rest of the board disagreed with Harvey, the only member in favor of a mandatory busing plan. ${ }^{43}$

The board continued to push a voluntary policy by reorganizing the city's most segregated school. Grant Elementary School, a school with a student population that was 99 percent black in 1967, would be reconfigured as an integration academy in the fall of 1970. It would become a magnet school that would house the Bridgeway Project - a school modeled on the Martin Luther King Jr. Laboratory School in Evanston, Illinois, which attracted white students to a previously mostly black school by providing the kind of cutting-edge pedagogical innovations

41. School Board Minutes, 4/7/1969.

42. School Board Minutes, 5/26/1969; Waterloo Courier, 5/13/1969.

43. Waterloo Courier, 10/28/1969. 


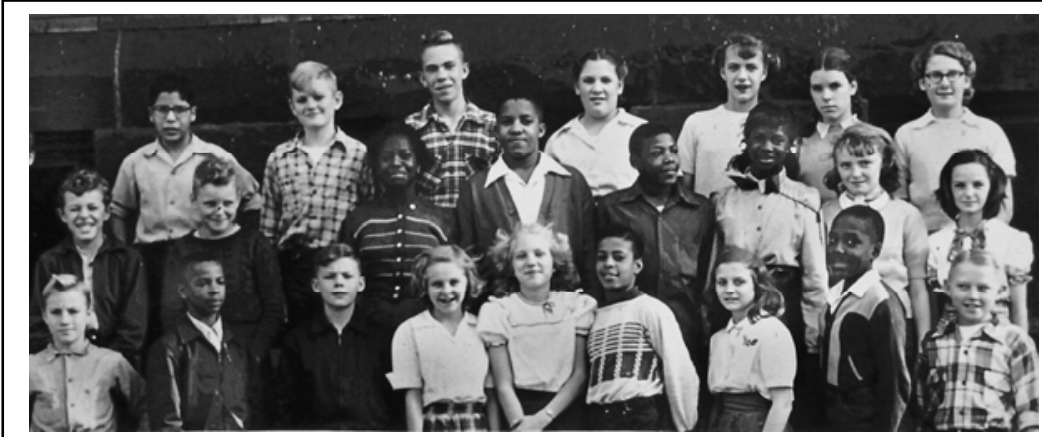

Students in an integrated classroom at Waterloo's Grant Elementary School pose for a class picture. Photo courtesy Reasby family.

found in laboratory schools. ${ }^{44}$ The central idea behind the creation of such schools was that districts could persuade-rather than force-white parents to send their children to desegregated schools. It was an effective idea. When Grant School opened in the fall of 1970, it had a nearly perfect fifty-fifty balance of African American and white children. The Bridgeway Project was able to draw white students to a school that in previous years had had almost none, although it also displaced half of the black children previously enrolled at Grant who had to transfer to other schools. With few other white students choosing to transfer to schools with high concentrations of black students, the burden of desegregation was placed on the shoulders of African American children, just as Harvey had predicted. ${ }^{45}$

By 1970, voluntary school desegregation had failed, except at Grant School, to create meaningful change. Only 30 African American students attended West High, and none attended Orange High. Almost all of the district's African American high school students remained at East. ${ }^{46}$ Efforts were more successful

44. Waterloo Courier, 7/28/1967. Magnet schools were popularized in the 1960s and 1970s as a way to promote voluntary desegregation. See Christine H. Rossell, The Carrot or the Stick for School Desegregation Policy: Magnet Schools or Forced Busing (Philadelphia, 1990); and Kimberly C. West, "The Desegregation Tool That Backfired: Magnet Schools and Classroom Segregation," Yale Law Journal 103 (1994), 2567-92.

45. DPI, "Report on School Desegregation and Integration," 35.

46. "Waterloo Community Schools: Minority Group Survey for Annual Evaluation Report," School Board Minutes, 9/18/1970. 
at the elementary level, with African American students enrolling at all but 8 of the city's 30 schools. In theory, this was a victory for voluntary desegregation. A comprehensive look at the city's schools told another story - one that the school board did not want to see. Between 1967 and 1970, although black students were no longer isolated in a small fraction of the city's schools, the percentage of students at schools that already had high concentrations of black students did not decrease; in many cases it actually increased. Such was the case at City View Elementary, which went from 86 to 90 percent black over the span of three years. The percentage of black students at Frances Grout School increased from 23.5 percent to 32.2 percent; Hawthorne Elementary's black population also increased by nearly 10 percent to 52 percent. The percentage of black students at Longfellow and Roosevelt Elementary increased incrementally; both continued to have disproportionate percentages of black students. The percentages at Logan Junior High and East High School also increased, from 30 to 35 and 21 to 23 percent, respectively. ${ }^{47}$ In other words, as voluntary desegregation programs were implemented, not only were schools that had previously been all white increasing their percentages of black students, but so were schools that were already highly segregated. As the proportion of African American students in the district steadily increased between 1967 and 1970, both segregation and desegregation increased.

Desegregation was once again pushed onto the school board's agenda in late 1971. A new series of civil disturbances in the spring meant that the board could no longer simply rely on token desegregation. In November 1971 the state Department of Public Instruction (DPI) released a report on segregation in Waterloo schools that recommended immediate desegregation. The report, the culmination of a half-year investigation by the DPI, reignited the debate over desegregation and inflamed criticism of the school board's lackadaisical policy. The NAACP threw its support behind immediate implementation of the state proposal. "There has been too long a delay, and it is the respon-

47. "Comparison Showing Changes in Minority Group Distribution, 19631970," School Board Minutes, 10/2/1970. 
sibility of the members of the Board of Education to act," Robert Wright Sr., regional director of the NAACP, told the board. "Failure to act would be indefensible." Yet the board, on a 4 to 2 vote in December, defeated a motion for immediate desegregation. ${ }^{48}$

The state's report also sparked organizing by parents who opposed mandatory busing but who had previously been silent on the issue of voluntary desegregation. Within a week of the issuance of the report, more than two thousand parents attended a meeting of the newly formed Neighborhood Schools Association (NSA). "I'd like to say thank you to the state Department of Public Instruction and the school board for their help in the membership drive," the organization's president joked at the meeting. ${ }^{49}$ The NSA styled itself as "a new organization whose sole purpose is to strive to preserve the traditional neighborhood school concept." Fearing that the school board would impose mandatory busing to achieve meaningful desegregation, the organization sought to discourage sitting school board members from voting for desegregation. At the same time, the NSA campaigned for candidates who claimed to oppose any form of busing. ${ }^{50}$ NSA members devoted themselves to attending school board meetings en masse to prove their anti-busing mettle to the school board.

While some white parents were organizing on the side of neighborhood schools, the local teachers' union, the Waterloo Education Association (WEA), made an open-ended commitment to the principle of total integration. Although it did not go so far as to endorse a busing plan, the WEA stated that teachers did "recognize the need for and the advantages of a completely integrated public school, and thereby committed themselves to helping formulate any program that would bring this about." The WEA argued that socialization across the color line was essential for the positive development of all children in the city and was necessary for full participation in American life. The WEA's newly established Human Relations Commission stated,

48. Remarks by Robert A. Wright Sr., School Board Minutes, 12/13/1971; Waterloo Courier, 12/14/1971.

49. Waterloo Daily Courier, 11/3/1971.

50. Robert Clark to W. Harold Hartman, 10/8/1971, in School Board Minutes, 10/25/1971. 
"The purpose of the Human Relations program for the Waterloo Education Association is to try to achieve now what the original 'melting pot' was supposed to do when this country was settled. To do this it will be necessary for people to get to know and become more involved with each other." 51 The WEA echoed the sentiment of others that school segregation was bad not just for African Americans but for everyone. In the organization's statement, the color line was the primary problem and desegregation of schools its most effective solution.

At the next meeting of the school board in January, Dr. Harvey once again pushed the board to take a firm stand on desegregation. He presented ten recommendations to accomplish "total integration" and end the voluntary desegregation system, including hiring more black teachers, principals, and administrative personnel and implementing more forceful measures to eradicate racism in the schools. Harvey also recommended the purchase of new materials for classrooms and libraries that integrated African American history. The League of Women Voters issued a statement in support of total integration, stating, "We do believe that the adoption of a workable plan is urgently needed for the goal of quality and equal education for Waterloo children-both black and white." Despite the support of a growing coalition - the WEA, the League of Women Voters, and the NAACP - the board voted down the measure. ${ }^{52}$

In the following weeks more organizations joined the WEA, the NAACP, and the League of Women Voters in support of Harvey's proposal for mandatory desegregation. The Waterloo Women's Civic Club denounced the board's vote on the issue. The organization's president accused the board of giving false reasons for delaying action. "We are forced to believe that sincere honesty is not being demonstrated in this matter of school integration," she wrote in a letter to the president of the school board. Parents of the children enrolled in the Bridgeway Project at Grant School submitted a letter that was also read at the meeting, stating their support for further desegregation in the city. "We ... have experienced the value of quality education in an

51. School Board Minutes, 11/22/1971.

52. School Board Minutes, 1/10/1972. 
integrated setting," the statement read. "Because of this experience we strongly urge the Board of Education to rapidly expand this kind of educational opportunity throughout the entire system." 53

Chastened by the overwhelming community response but still reluctant to act, the board approved a measure to "give careful thought and study to the ten proposals of Dr. Harvey" and discuss them again at the next meeting. The board agreed to redraw the high school boundaries, a move that would transfer some black students from East High to the newly built Central High School and slightly increase the number of African American students at West High. ${ }^{54}$

The board's actions failed to address any other facets of racial discrimination in the schools, and so ignited more community controversy just a few months later in the spring of 1972. In late May, Alice Hayes, a speech teacher at West Junior High School-a school that had had no black students before the start of open enrollment-read her class a story, "Little Brown Koko and the Preacher's Watermelon," as a part of her class's unit on "dialect." The story described Koko's "little wooly head" and his "nice, good, old, fat, black Mammy" - tropes that relied on nostalgic depictions of slavery. An African American student in the class, upset by the racist portrayal of blacks in the story, complained to the vice principal, who failed to address the issue with Hayes. A group of concerned parents then met with the district's school and community relations coordinator, but that meeting, too, failed to result in any substantial action. ${ }^{55}$

The incident threatened to send the city into disorder, as had student protests at East High four years prior. The following week, approximately 30 parents walked into Alice Hayes's classroom and refused to leave until she was fired. "Any teacher that can teach this kind of thing shouldn't be allowed to teach in this system or even state," one appalled parent stated. The school's principal, Joseph Doyle, sent Hayes home for the day, but the parents refused to leave unless she was dismissed from

53. School Board Minutes, 1/24/1972.

54. Ibid.; Waterloo Courier, 1/23/1972.

55. Waterloo Courier, 5/24/1972. 
her position. When Doyle balked at their request, they insisted that he also be fired, accusing him of implicitly condoning Hayes's actions. Two days later, 150 black parents and children entered the Waterloo School District Administration Building, demanding an audience with the superintendent. The group entered Superintendent George Diestelmeier's office and presented him with a list of demands. When Diestelmeier attempted to leave, it became clear that he would have to walk on or over parents and small children in order to get out. The parents and children held the superintendent in his office for five hours before an injunction forced them to leave. ${ }^{56}$

While Diestelmeier sat with the parents, the school board met in an emergency meeting at an elementary school. The board voted to support the administration's current policies; Harvey, still the lone African American member of the board, voiced his displeasure by abstaining from the votes. The next day the school board met again, this time voting to reinstate Hayes. Not every board member approved of the decision. Reverend Gamb, the only other board member besides Harvey who favored forced desegregation, accused the other members of being "hell bent on inflaming the situation." 57

While African American parents kept their children home from school to protest the school board's failure to act, approximately 100 white students staged a walkout in support of Hayes. The controversy over Alice Hayes became increasingly heated in the following week as protests spread out into the community and elicited a violent response. Frustrated by the board's actions, the protesters who had been ejected from the superintendent's office regrouped and began boycotting the city's shopping center, Logan Center Plaza. They announced that they would picket the plaza until the school board acquiesced to their demands, hoping that the boycott would pressure the business community into influencing the board's decisions. Boycotters and white shoppers accused each other of assault. One white man was arrested for attacking picketers with a wrench, and a white woman called the police after she claimed that protesters knocked her to the

56. Waterloo Courier, 5/24/1972, 5/26/1972.

57. School Board Minutes, 5/26/1972. 
ground. Concerned that the situation might escalate into widescale civil disorder, the city set up a "rumor control" phone line, and the U.S. Department of Justice sent a field representative to Waterloo to help the city control the crisis. 58

During the summer of 1972, the school board and various pro- and anti-desegregation forces in the community were at an impasse. In July the NAACP filed a lawsuit accusing the school district of deliberately segregating the schools, but still the board did not budge. ${ }^{59}$ What ultimately ended the standoff was something that few anticipated: demographic change.

WITH FEWER CHILDREN in Waterloo schools, the school board faced the need to close schools. Enrollment statistics for the 1972-73 school year showed a significant decrease in the number of children enrolled in Waterloo public schools. ${ }^{60}$ Fewer students meant that the district would receive less funding from the state. The superintendent and school board realized that the district would not be able to pay its bills in the upcoming year. Projections for the next five years anticipated a loss of 3,000 public school students in the district due to demographic change. ${ }^{61}$

Federal funds for desegregation through the Emergency School Aid Act of 1972 provided a way for the district to ease the process of school reorganization with minimal financial commitment from the district. Persuaded by the numbers, in February 1973 board president James Sage wrote an open letter to the other members of the board calling for complete desegregation. "We cannot continue to rear our children in a community which has so much distrust and fear between the races," Sage wrote. "If we want new industries and business to come and provide jobs for our children in the future, we are going to have to realize that the community must attempt to solve the racial feelings that have developed, otherwise the community will 'wither away.'" 62 The Neighborhood Schools Association

58. Waterloo Courier, 5/26/1972, 6/1/1972.

59. USCCR, "School Desegregation in Waterloo," 9-10.

60. Waterloo Courier, 10/12/1971.

61. Waterloo Courier, 3/18/1973.

62. Waterloo Courier, 2/13/1973. 
shared Sage's ideas in principle, agreeing that distrust and fear must be the target of community action. The point of disagreement, NSA head Harold Getty noted, was the place where this battle must be fought. "We do not agree with his suggestion that the school district is the only institution that should attempt the task of social change since no one else does," Getty wrote in response to Sage's open letter. ${ }^{63}$ The district's financial situation may have changed the minds of board members, but the NSA remained firmly opposed to mandatory desegregation.

Larger demographic shifts were primarily behind the declining enrollment in Waterloo's public schools. In Waterloo the total public school population was decreasing while the percentage that was African American was increasing steadily. The Waterloo Community School District lost more than 1,200 white students in just four years -7.5 percent of its entire white student population. The increase in the number of African American students was less dramatic than the declining number of white students, as there were about 85 more black students in the system in 1973 than in 1969. ${ }^{64}$ The loss of white students was due at least in part to the aging of the white population. Between 1956 and 1966, Iowans' birth rate fell by nearly a third. 65 The shrinking enrollment of white students in Waterloo's public schools was not due to large-scale white flight from the city or the schools, as Waterloo's population was actually growing during these years, not declining. Nor can general city population increases be wholly attributed to the in-migration of African Americans. ${ }^{66}$ And there is no evidence that the decline was caused by large-scale enrollments in parochial schools, as the

63. Harold Getty to the Waterloo Board of Education, 3/12/1973, folder 4, box 1, James Sage Papers.

64. Racial Ethnic Census Report, Iowa Public Schools: Supplement to Racial Ethnic Census Report 1970 (Des Moines, 1970).

65. According to the State Department of Public Instruction, the birth rate in Iowa fell 29 percent between 1956 and 1966. See Burlington Hawkeye, 4/15/1968, in folder: Schools, Elementary and Secondary, July 1967-Dec. 1968, box 33, Harold Hughes Collection-Gubernatorial Papers, Special Collections, University of Iowa Libraries, Iowa City.

66. Between 1960 and 1970, Waterloo's population increased by 5.3 percent. Iowa Development Commission, 1972 Statistical Profile of Iowa (Des Moines, 1972), 39. 
decline in white student enrollments began before the student unrest in 1968.67 At the precise moment that the Waterloo school district sought to implement integration, it was undergoing a dramatic shift in the population of those very schools.

These trends were evident not only at the local level; they were indicative of a larger trend in Iowa that created an age gulf between the white and black populations. Statewide, in 1970 the median age of African Americans was 21.1, whereas the median age of whites was 29.0. The median age of black men was even lower, 20.3, versus 27.6 for white men. ${ }^{68}$ In Waterloo, this shifting population could be seen in the ages of schoolchildren. The school population peaked in 1967, with roughly 19,700 children enrolled in Waterloo public schools. The projected school enrollment for 1976 was just 16,272, and almost all of the loss was in lower grades. While the number of high school students in Waterloo remained fairly constant, fluctuating by only a few dozen throughout the 1960s and early 1970s, the number of elementary school children dropped dramatically, from a high of 11,388 in 1967 to only 9,682 in 1973. ${ }^{69}$ An increase in parochial school enrollment during the early 1970s also contributed to the phenomenon, although not by enough to account entirely for declining enrollment in Waterloo public schools. ${ }^{70}$ Given these trends, compounded by the influx of new African American children, it is not surprising that segregation was rapidly increasing in Waterloo schools during this period. It is also likely that the prominence of school issues in community debates during this period had much to do with this dramatic change. The white population of Waterloo was increasingly older, while its young population was increasingly African American.

Faced with declining enrollment, increasing segregation, and recurrent protests within Waterloo's public schools, the school board began considering potential plans that would close schools, create a more efficient use of classroom space, and alleviate the increasing segregation of black children in city schools. The

67. USCCR, “School Desegregation in Waterloo," 11.

68. Iowa Development Commission, 1972 Statistical Profile of Iowa, 34.

69. “Waterloo Community Schools Enrollments," folder 1, box 1, James Sage Papers.

70. Waterloo Courier, 9/11/1973. 
plans were introduced at a board meeting on March 12, 1973. All of the plans involved boundary changes, but the most popular was Plan A, which proposed pairing and combining schools with high and very low percentages of African American students and closing three of the city's oldest elementary schools. Plan A aligned elementary and junior high school attendance zones with those of the new high school zones so that groups of students would move together through the new system and not be scattered as they transitioned from elementary to junior high schools, and then from junior high to high schools. It also minimized the need for busing, as a third of the students who would be reassigned remained within walking distance of their new schools. The plan required the addition of only five buses to the district's existing fleet of sixty. ${ }^{71}$

The board planned a vote on the proposed plans on April 5, 1973. Because of the large turnout, the school board meeting was held at West High School-the same place, nearly five years earlier, where unrest had broken out at the football game with East High and forced city residents to acknowledge and address problems of the city's youth: racial discrimination and segregation in schools. Six hundred people showed up at the school board meeting, many bearing signs voicing opposition to desegregation.

Consensus from community groups who supported desegregation coalesced in support for Plan A. A local doctor read a statement in support of Plan A, which stressed that schools should be the crucible of American democracy. "The concept of an open society is a cornerstone of our national conscience. . . . Forced isolation breeds fear and is a burden and threat to all of us. It is with this goal of an open and just society that we urge you to adopt Plan A. It is a small but positive step toward helping this community regain its health and self respect." 72 The local branch of the American Association of University Women likewise applauded Plan A's attack on a "closed society." According to AAUW President Cecile Powers, the organization sup-

71. "Minority Isolation Reduction, Plan 'A,'” School Board Minutes, 4/5/1973.

72. Waterloo Courier, 4/6/1973; Statement by Braden Stevenson to the School Board, 4/5/1973, folder 6, box 1, James Sage Papers. 
ported "educational programs essential to a democratic society" through "programs directed toward improved intergroup and interpersonal relations necessary in an ethnically pluralistic society." The League of Women Voters, the Waterloo Education Association, and the Title VII Advisory Committee all joined in support of Plan A. ${ }^{73}$

The Neighborhood Schools Association disapproved of all the reorganization plans, although the organization offered no alternative solutions to the funding crisis. It was joined by the tepid opposition of the Waterloo Council of PTAs, which expressed concern about the school board's apparent neglect of parents" "negative feelings toward forced busing of their children." The NSA and the PTA council suggested that the board continue to discuss the issue and create more advisory councils. Their position was bolstered by the support of more than 500 citizens who opposed all of the plans, as they all required the closing of Lafayette School. Even though desegregation would only incrementally increase the number of children being bused within the Waterloo school district, Lafayette School parents believed that "it would be mass murder to expect our children to cross a four lane highway ... to attend a school." One white mother, who had five children in city schools, accused the school board of attempting to "sell the children of the Waterloo School District into the slavery of statistics for Federal Aid." Growing support for desegregation and school reorganization led the opposition to resort to increasingly inflammatory comments about the fate of white children in a desegregated school system. ${ }^{74}$

Despite the mother's admonition not to "hang another millstone around the necks of our children," the protestations of the opposition groups went unheeded. On April 5, 1973, the board voted 4 to 3 to approve Plan A. Even in the face of grassroots mass resistance by white parents, the school board refused to discard desegregation as a necessary complement to school reorganization. After the vote was taken, half the parents in at-

73. Cecile Powers to James Sage, 4/15/1973, in School Board Minutes, 5/7/ 1973; School Board Minutes, 4/5/1973.

74. School Board Minutes, 4/5/1973. In 1973 the school district already bused 2,460 children. Plan A would increase that number by roughly 600 . Folder 6 , box 1, James Sage Papers. 
tendance got up and walked out in protest, chanting "Freedom! Freedom!" and "Let's have another Pontiac!" (referring to the efforts of white parents in Pontiac, Michigan, to oppose desegregation efforts there in a movement that made national headlines when Klansmen bombed 13 school buses that were to be used in the city's new desegregation plan). ${ }^{75}$

The approval of Plan A marked a watershed moment. It indicated that the school board had finally committed to substantive reform. Those who opposed desegregation wrote vitriolfilled letters to Sage and the superintendent, threatening their lives and, in one case, labeling them "yellow-bellied bastards." 76 Despite the continued protests against busing, once the plan was approved, the school board remained committed to its desegregation plan. Although Sage lost his seat in the fall's school board election, the new NSA-endorsed members did not block the implementation of Plan A. ${ }^{77}$ After years of struggle, racial reform in the schools was finally codified in school board policy.

THE SUCCESS of the desegregation plan masked what had been lost in the course of turning protest into policy. Although students had initiated school reform, the results looked little like what they had imagined in 1968. Young people got the attention that they demanded, but that only partially achieved their goals. Their radical ideas could have dramatically reshaped schools for all students in the city, making education more democratic and equitable across lines of race and class. The struggle over the schools threatened traditional sources of authority, including the school board and East High's administration, and brought children into the decision-making process for the first time. The civil disorder of the autumn of 1968 effectively turned attention toward the young people's complaints, but it also turned the debates away from the specific demands of the students and toward a more community consensusoriented solution: desegregation.

75. Waterloo Courier, 4/6/1973; New York Times, 9/10/1971.

76. Anonymous letter to George Diestelmeier, 5/17/1973, folder 1, box 2, James Sage Papers.

77. USCCR, "School Desegregation in Waterloo," 30. 
School desegregation became a panacea designed to cure the ills of racial discrimination in Waterloo schools. It was a public policy that could signal the city's commitment to an integrated "open" society, but it failed to address many of the ways that racial discrimination continued to affect life for African American children in the city. The democratic process of implementing desegregation made the issue itself one that was inflected with the basic idea of community. That process became a proxy for debates about life in a democratic society. Civil disorder led to the creation of a plan for school desegregation, which in turn ignored many of the students' basic requests and flattened ideas about race, rights, and civic belonging. The local nature of the implementation of civil rights reform allowed individuals more power in the formation of policies, but it also brought more competing voices into the debate. As residents of Waterloo debated the benefits and drawbacks of desegregating their schools, the discussion shifted from one that centered on restorative justice for black children to one that emphasized the benefits of desegregation for all children and the city itself.

The photograph on page 363 should have been credited to photographer David Weldon. We regret the omission. 